Marta Czech

Uniwersytet $w$ Biatymstoku

\title{
DZIAŁANIA STAROSTY W PROCEDURZE WYWŁASZCZENIA NIERUCHOMOŚCI NA CELE ZWIAZZANE Z OCHRONĄ ŚRODOWISKA
}

\section{Wprowadzenie}

Szeroko pojmowana ochrona środowiska $\mathrm{w}$ wielu przypadkach powoduje przeciwstawienie sobie interesu publicznego i interesu prywatnego. Dwa najczęściej występujące konflikty na tym polu to ochrona środowiska a prawo własności oraz ochrona środowiska a działalność gospodarcza. Dochodzi do tego pomimo samych założeń zrównoważonego rozwoju, które zgodnie z pkt 50 art. 3 ustawy Prawo ochrony środowiska ${ }^{1}$ (dalej p.o.ś.) polegają na integrowaniu działań, harmonijnym łączeniu interesów jednostki z interesem publicznym. Konflikt interesów jest jednak nieodłącznym elementem życia w zbiorowości. Do jego łagodzenia służą normy prawa cywilnego i administracyjnego oraz zasady współżycia społecznego. Bardzo rzadko jednak możliwe jest pogodzenie interesów bez uszczerbku dla żadnej ze stron. W gestii państwa leżą natomiast takie działania faktyczne i takie ukształtowanie ustawodawstwa, by nie przyznawać bezwzględnego prymatu jednemu z nich. Zgodnie z art. 5 Konstytucji Rzeczpospolitej Polskiej² państwo ma działać, kierując się zasadą zrównoważonego rozwoju. Jest to zasada o charakterze dyrektywalnym, wiąże organy administracji publicznej przy dokonywaniu wykładni prawa oraz pełni rolę podobną do zasad współżycia społecznego lub społeczno-gospodarczego przeznaczenia prawa $\mathrm{w}$ prawie cywilnym. ${ }^{3}$ Ponadto $\mathrm{w}$ prawie administracyjnym funkcjonuje zasada wyważania interesów, przejawiająca się w takim rozstrzyganiu spraw, które polega na proporcjonalnym uwzględnianiu dobra jednostki i społeczeństwa. ${ }^{4}$

Ustawa z dnia 27 kwietnia 2001 r. Prawo ochrony środowiska, t. j. Dz.U. z 2013 r. poz. 1232.

Konstytucja Rzeczypospolitej Polskiej z dnia 2 kwietnia 1997 r., Dz.U. Nr 78, poz. 483 ze sprost. i zm.

Wyrok WSA w Gorzowie Wielkopolskim z dnia 27 listopada 2008 r., II SA/Go 510/08, Legalis nr 259059.

I. Sierpowska, Wywłaszczeniowe postępowanie administracyjne. Wybrane zagadnienia, „Acta Universitatis Wratislaviensis, Przegląd Prawa i Administracji” 2007, nr LXXVI, s. 246. 
Instytucją prawną, która z konfliktem interesu prywatnego z publicznym, a konkretniej z konfliktem między prawem własności a ochroną środowiska, kojarzy się automatycznie, jest wywłaszczenie nieruchomości. Konstrukcja ta ma charakter interdyscyplinarny, gdyż przenika przez prawo konstytucyjne, administracyjne i cywilne. Zgodnie z ustawową definicją zawartą w art. 112 ust. 2 i 3 ustawy o gospodarce nieruchomościami (dalej u.g.n.), ${ }^{5}$ wywłaszczenie jest aktem administracyjnym polegającym na pozbawieniu albo ograniczeniu, w drodze decyzji, prawa własności, prawa użytkowania wieczystego lub innego prawa rzeczowego na nieruchomości. Jednakże może to zostać dokonane tylko wtedy, jeśli cele publiczne nie mogą zostać zrealizowane w inny sposób niż przez pozbawienie albo ograniczenie praw do nieruchomości, a prawa te nie mogą być nabyte w drodze umowy. Ustawa o gospodarce nieruchomościami jest fundamentalnym aktem regulującym przedmiotową instytucję i to na jej przepisach głównie skupię swoją uwagę.

Instytucja wywłaszczenia nieruchomości jest zagadnieniem od lat budzącym, oprócz teoretycznych sporów doktrynalnych, równie wiele kontrowersji i emocji w praktyce życia codziennego. Jest jedną z najbardziej dolegliwych form ingerencji publicznoprawnej w sferę praw jednostki, godzi w prawo, do którego jesteśmy od pokoleń na tyle silnie przywiązani, że jego ochrona stanowi działanie nieomal instynktowne. Dlatego jest ona przedmiotem regulacji na poziomie krajowym, przede wszystkim w Konstytucji Rzeczpospolitej Polskiej, Kodeksie cywilnym ${ }^{6}$ czy Kodeksie karnym, ${ }^{7}$ na poziomie unijnym, m.in. w Karcie Praw Podstawowych, ${ }^{8} \mathrm{czy}$ też międzynarodowym w Powszechnej Deklaracji Praw Człowieka i Obywatela. ${ }^{9}$ Zaistnienie celu publicznego, do którego realizacji niezbędne okazuje się wywłaszczenie, jest równoznaczne z powstaniem konfliktu interesów jednostki i państwa. Nie sposób konfliktu tego rozwiązać bez uszczerbku dla podmiotu wywłaszczanego. Jednak ustawodawca próbuje wyrównać pozycję podmiotu wywłaszczanego za pomocą należnej mu rekompensaty w postaci słusznego odszkodowania. W przeciwnym wypadku utrata prawa do nieruchomości miałaby cechy ofiary jednostki na rzecz państwa i społeczeństwa. Odszkodowanie jest elementem różniącym wywłaszczenie od innych form ingerencji publicznoprawnej w prawo własności jednostki, takich jak nacjonalizacja czy konfiskata. Obecnie na mocy art. 134 ust. 1 u.g.n. podstawę ustalenia wysokości odszkodowania stanowi wartość rynkowa nieruchomości, natomiast szacunku dokonuje się w oparciu o opinię rzeczoznawcy majątkowego z zakresu wyceny nieruchomości.

$5 \quad$ Ustawa z dnia 21 sierpnia 1997 r., t.j. Dz.U. z 2014 r. poz. 518.

$6 \quad$ Ustawa z dnia 23 kwietnia 1964 r. Kodeks cywilny, t.j. Dz.U. z 2014 r. poz. 121.

7 Ustawa z dnia 6 czerwca 1997 r. Kodeks karny, Dz.U. Nr 88, poz. 553 ze zm.

8 Dz. Urz. UE 2012 C 326, s. 2, dostępne:http://eur-lex.europa.eu/LexUriServ/LexUriServ.do?uri=OJ:C:2010:083:0 389:0403:pl:PDF (data dostępu: 05.07.2013 r.).

9 Dostępne: http://www.unesco.pl/fileadmin/user_upload/pdf/Powszechna_Deklaracja_Praw_Czlowieka.pdf (data dostępu: 05.07.2013 r.). 
Cel publiczny jest klauzulą generalną, która do dziś nie doczekała się konkretyzacji i systematyzacji w formie jednolitej definicji. Podzielam pogląd m.in. J. Szachułowicza, że definicji takiej po prostu nie sposób stworzyć, ze względu na brak stałego, trwałego i niezmiennego przedmiotu tej definicji. Nie oznacza to oczywiście, że na gruncie nauki prawa nie są widoczne próby określania, co należy rozumieć pod pojęciem cel publiczny. Pośród nich najtrafniejszą wydaje mi się funkcjonalna definicja M. Wolanina, który za cele publiczne uznaje wszystko to, osiągnięciu czego służą poszczególne cele wskazane w art. 6 u.g.n. ${ }^{10}$ Do celów w zakresie ochrony środowiska należy na pewno zaliczyć budowę oraz utrzymywanie publicznych urządzeń służących do zaopatrzenia ludności w wodę, gromadzenia, przesyłania, oczyszczania i odprowadzania ścieków oraz odzysku i unieszkodliwiania odpadów, w tym ich składowania (art. 6 pkt 3 u.g.n.), obiektów i urządzeń służących ochronie środowiska, zbiorników i innych urządzeń wodnych służących zaopatrzeniu w wodę, regulacji przepływów i ochronie przed powodzią, a także regulację i utrzymywanie wód oraz urządzeń melioracji wodnych będących własnością Skarbu Państwa lub jednostek samorządu terytorialnego (pkt 4), czy też ochronę zagrożonych wyginięciem gatunków roślin i zwierząt lub siedlisk przyrody (pkt 9b). Natomiast jeśli chodzi o zrównoważony rozwój, zagadnieniu temu odpowiada większość z celów ujętych w katalogu art. 6, na czele z budową i utrzymywaniem dróg, linii kolejowych i lotnisk, czy też opieka nad nieruchomościami stanowiącymi zabytki.

Dla pełniejszego przedstawienia wywłaszczenia nieruchomości należy jeszcze krótko wspomnieć o zakresie przedmiotowym i podmiotowym tej instytucji na podstawie przepisów u.g.n. Wywłaszczeniu mogą podlegać następujące prawa na nieruchomości: własność, użytkowanie wieczyste, inne prawa rzeczowe. W literaturze nie gaśnie jednak spór o to, czy przedmiotem wywłaszczenia są nieruchomości, czy też prawa na nich. Dopuszczalne jest też wywłaszczenie części nieruchomości, jednak problemy na gruncie nauki prawa i judykatury powoduje kwestia dopuszczalności wywłaszczenia udziału we współwłasności nieruchomości. Ustawa o gospodarce nieruchomościami enumeratywnie wymienia podmioty, na rzecz których następuje wywłaszczenie, jest to Skarb Państwa i jednostka samorządu terytorialnego. Nie ujmuje natomiast konkretnie podmiotów, które mogą zostać wywłaszczone, co pozostawia pole do działania przedstawicielom nauki prawa. Dominującą opinią jest, że zakres podmiotowy wywłaszczenia odpowiada zakresowi podmiotowemu praw, które podlegają ewentualnemu wywłaszczeniu. ${ }^{11}$ Konkretyzując, wywłaszczone mogą zostać osoby fizyczne, prawne oraz jednostki organizacyjne nieposiadające osobowości prawnej, którym przysługuje prawo własności, użytkowania wieczystego lub ograniczone prawo rzeczowe względem nieruchomości, poza Skarbem Państwa w odniesieniu do jego prawa własności. To ostatnie zastrzeżenie wynika

\footnotetext{
10 M. Wolanin, Cel publiczny jako normatywne kryterium oddziaływania na stosunki cywilnoprawne w gospodarowaniu nieruchomościami, cz. I, „Nieruchomości” 2009, nr 9, s. 6.

11 M. Szalewska, Wywłaszczenie nieruchomości, Warszawa 2005, s. 180-181.
} 
w sposób bezpośredni z regulacji zawartej w art. 113 ust. 2, uniemożliwiającej wywłaszczenie nieruchomości stanowiącej własność Skarbu Państwa, ale dopuszczającej je w przypadku prawa użytkowania wieczystego i ograniczonych praw rzeczowych.

\section{Rola starosty w postępowaniu wywłaszczeniowym}

Postępowanie w sprawach o wywłaszczenie nieruchomości należy zakwalifikować jako administracyjne postępowanie jurysdykcyjne. ${ }^{12}$ Świadczy o tym fakt, że jest to postępowanie w indywidualnej sprawie administracyjnej, należącej do właściwości organów administracji publicznej, rozstrzyganej w drodze decyzji administracyjnej. Przepisy regulujące tę procedurę zawarte są w u.g.n. oraz w Kodeksie postępowania administracyjnego ${ }^{13}$ stanowiącego wobec niej lex generalis. $\mathrm{W}$ art. 112 ust. 4 u.g.n. ustawodawca organem właściwym w sprawach wywłaszczenia mianował starostę wykonującego zadania z zakresu administracji rządowej. Tak określoną właściwość rzeczową uzupełnia właściwość miejscowa ustalana na podstawie zasad wynikających z k.p.a., a mianowicie właściwym będzie starosta, na którego obszarze działania położona jest nieruchomość będąca przedmiotem wywłaszczenia (w przypadku kilku powiatów bierze się pod uwagę położenie największej części nieruchomości). W związku z powyższym, organem wyższego stopnia będzie wojewoda. ${ }^{14}$

W poprzednim stanie prawnym, a konkretnie do momentu nowelizacji po reformie ustrojowej państwa w 1999 r. organem właściwym do prowadzenia postepowania wywłaszczeniowego był wojewoda, natomiast organem odwoławczym był Prezes Urzędu Mieszkalnictwa i Rozwoju Miast. Jeszcze wcześniej były to rejonowe organy rządowej administracji ogólnej, czyli kierownicy urzędów rejonowych, właściwych ze względu na położenie nieruchomości ${ }^{15} \mathrm{~W}$ związku z przesunięciem kompetencji w procedurze wywłaszczeniowej z wojewody na starostę, nasuwa się pytanie, czy zmiana ta ma wydźwięk pozytywny czy raczej negatywny? Po przeanalizowaniu poglądów przedstawicieli nauki prawa oraz stanowisk judykatury wydaje mi się, że podstawą do pozytywnej oceny może być fakt, iż starosta jest organem administracji samorządowej, zatem bliższego obywatelowi szczebla władzy. Ponadto przesunięcie kompetencji na starostę powinno wpłynąć na przyspieszenie postępowania wywłaszczeniowego. Biorąc pod uwagę, że w województwie podlaskim funkcjonuje 14 starostów i 1 wojewoda, ${ }^{16}$ proporcje te mówią same za siebie.

T. Woś, Wywłaszczenie nieruchomości i ich zwrot, Warszawa 2012, s. 199.

Ustawa z dnia 14 czerwca 1960 r. - Kodeks postępowania administracyjnego, t.j. Dz.U. z 2013 r., poz. 267.

E. Mzyk, (w:) S. Kalus (red.), Ustawa o gospodarce nieruchomościami. Komentarz, Warszawa 2012, s. 671.

M. Szalewska, Postępowanie wywłaszczeniowe, „Samorząd Terytorialny” 1998, nr 7-8, s. 68.

http://bip.wrotapodlasia.pl/starostwa.html (data dostępu: 05.07.2013 r.). 
W niniejszym opracowaniu poruszam problem procedury wywłaszczeniowej sensu largo, czyli od momentu wszczęcia rokowań do chwili, kiedy decyzja o wywłaszczeniu staje się ostateczna. W takim rozumieniu przedmiotowego zagadnienia pierwszym zadaniem należącym do starosty jest przeprowadzenie rokowań. Jest to etap poprzedzający wszczęcie właściwego postępowania wywłaszczeniowego, jego celem jest nabycie nieruchomości w drodze cywilnoprawnej. Innymi słowy, starosta ma obowiązek podjęcia próby nabycia nieruchomości niezbędnej do zrealizowania celu publicznego, najpierw poprzez zawarcie umowy z jej właścicielem, użytkownikiem wieczystym lub osobą, której przysługują ograniczone prawa rzeczowe na niej, a dopiero w wyniku niemożliwości zawarcia umowy wszczynane jest postępowanie administracyjne. Warty zauważenia jest ust. 2 art. 114 u.g.n., zgodnie z którym, jeśli nieruchomość ma być wywłaszczona na wniosek jednostki samorządu terytorialnego, to rokowania prowadzone są nie przez starostę, a przez organy wykonawcze tych jednostek. Rokowania mają polegać na negocjacjach, dialogu pomiędzy stroną a organem, w którym wymienione zostają informacje dotyczące przedmiotu potencjalnej umowy, uzgodnione kolejno jej postanowienia. Zgadzam się z większością przedstawicieli doktryny twierdzących, że rokowania są warunkiem sine qua non wywłaszczeniowego postępowania administracyjnego. Z literalnego brzmienia art. 114 ust. 1 u.g.n. nie wynika bezwzględny obowiązek (,,Wszczęcie postępowania (...) należy poprzedzić rokowaniami (...)"), jednak pamiętać trzeba, że do wniosku o wywłaszczenie należy dołączyć dokumenty z przebiegu rokowań, a ponadto wywłaszczenie jako publicznoprawna, władcza ingerencja w prawo własności objęte tak szeroką ochroną prawną, jest rozwiązaniem wyjątkowym i ostatecznym. ${ }^{17}$

Po zakończeniu rokowań możliwe są dwie sytuacje. Po pierwsze, strona i organ mogą dojść do konsensusu co do przedmiotowej nieruchomości, skutkiem czego będzie zawarcie umowy nabycia nieruchomości. W takim wypadku nie ma podstaw do wszczęcia postępowania administracyjnego, nabycie następuje na zasadach Kodeksu cywilnego, ${ }^{18} \mathrm{~W}$ związku z czym bezpodstawne będą później m.in. takie roszczenia, jak roszczenie o zwrot nieruchomości, która ostatecznie nie zostanie wykorzystana na realizację celu publicznego. Warto podkreślić, że w takiej sytuacji najpełniej realizowana jest zasada zrównoważonego rozwoju. Dany cel publiczny zostaje wtedy osiągnięty za pomocą wyważenia racji oraz integracji działań obu stron, a element zrównoważenia uwidacznia się w ustawowym obowiązku przyznania słusznego odszkodowania. Drugie rozwiązanie zachodzi, gdy konsensus nie zostaje osiągnięty. Wtedy starosta ma obowiązek wyznaczyć właścicielowi, użytkownikowi wieczystemu bądź osobie, której przysługują ograniczone prawa rzeczowe, termin dwumiesięczny na zawarcie umowy, liczony od dnia zakończenia rokowań. Dopiero po 
upływie tego terminu może zostać wszczęte postępowanie wywłaszczeniowe sensu stricto.

Na etapie rokowań inaczej wyglądają działania starosty w przypadku nieruchomości o nieuregulowanym stanie prawnym. Zakres ten obejmuje sytuacje, w których nie można ustalić, komu przysługują prawa do nieruchomości, właściciel lub użytkownik wieczysty nie żyje i nie zostało przeprowadzone lub zakończone postępowanie spadkowe. Nie prowadzi się tu rokowań w postaci negocjacji ze stroną, $\mathrm{z}$ racji tego, że strony takiej w rzeczywistości nie ma. Zadaniem starosty jest wtedy na podstawie art. 114 ust. 3 poinformowanie o zamiarze wywłaszczenia danej nieruchomości. Powinno to zostać dokonane poprzez podanie do publicznej wiadomości w sposób zwyczajowo przyjęty w danej miejscowości, na stronach internetowych danego starostwa powiatowego, w prasie o ogólnopolskim zasięgu. Tutaj również został zakreślony 2-miesięczny termin od ogłoszenia. W tym czasie mogą zgłaszać się osoby, które wykażą przysługujące im prawa do nieruchomości, natomiast dopiero po upływie tego terminu można wszcząć postępowanie wywłaszczeniowe.

Po zakończeniu etapu rokowań, łącznie z upływem wspomnianego dwumiesięcznego terminu, następuje wszczęcie postępowania wywłaszczeniowego. Jego forma uzależniona jest od kryterium podmiotowego, na rzecz którego ma nastąpić wywłaszczenie. Jeśli podmiotem tym jest Skarb Państwa, wszczęcie odbywa się z urzędu, natomiast jeśli jednostka samorządu terytorialnego (j.s.t.) - na wniosek jej organu wykonawczego. Jak zauważa T. Woś, postępowanie z urzędu ma w u.g.n. inny wydźwięk niż w k.p.a., gdzie przyjęto konstrukcję postępowania, którego inicjatorem jest organ, który będzie je prowadził. ${ }^{19}$ Postępowania wywłaszczeniowego z urzędu nie wszczyna starosta, lecz inny organ administracji rządowej lub inny państwowy podmiot, m.in. wojewoda, dyrektor izby skarbowej. ${ }^{20}$ Natomiast starosta może wszcząć postępowanie wywłaszczeniowe na wniosek, gdy jego beneficjentem ma być powiat. Na tym polu powstaje jednak wiele wątpliwości, ponieważ w takiej sytuacji wydaje się, że starosta występuje w podwójnej roli - organu $-\mathrm{z}$ tego względu, że na mocy art. 112 ust. 4 u.g.n. prowadzi postępowanie wywłaszczeniowe, oraz strony - reprezentuje powiat jako przewodniczący organu wykonawczego, czyli zarządu. Pojawia się tu konflikt interesów również z racji tego, że powiat może występować jako strona postępowania, na której rzecz ma nastąpić wywłaszczenie, albo jako strona, której nieruchomość ma być wywłaszczona na rzecz Skarbu Państwa. Po pierwsze nie da się w takiej sytuacji mówić o bezstronności i obiektywizmie, a po drugie, przeczy to zasadzie nemo iudex in causa sua. W związku z tym najbardziej racjonalnym rozwiązaniem w tej sytuacji wydaje się wyłączenie starosty z postępowania i załatwienie sprawy przez organ wyższego stopnia. ${ }^{21}$ Podobnie

19 T. Woś, Wywłaszczenie..., op. cit., s. 88-89.

20 I. Sierpowska, Wywłaszczeniowe..., op. cit., s. 241; T. Woś, Wywłaszczenie..., op. cit., s. 211.

21 I. Sierpowska, Wywłaszczeniowe..., op. cit., s. 240-241. 
wypowiedział się Naczelny Sąd Administracyjny w przypadku gdy funkcje starosty pełnione są przez prezydenta miasta na prawach powiatu. ${ }^{22}$

Ustawa o gospodarce nieruchomościami bardzo skrótowo i lakonicznie wspomina o kompetencji starosty w zakresie odmowy wszczęcia postępowania wywłaszczeniowego. Przepisy k.p.a. natomiast w ogóle o tym nie traktują. Według art. 115 ust. 4 u.g.n. starosta może odmówić wszczęcia postępowania z wniosku organu wykonawczego j.s.t. lub podmiotu, który zamierza zrealizować cel publiczny, a odmowa ta ma przybierać formę decyzji. Nie uregulowano przy tym kwestii materialnoprawnych przesłanek ewentualnej odmowy. Ale z drugiej strony nie wydaje się, by tak istotna sprawa została pozostawiona swobodnemu uznaniu starosty. Zgadzam się z opinią E. Mzyka, który opowiada się za obowiązkiem starosty wszczęcia postępowania wywłaszczeniowego $\mathrm{w}$ obliczu zaistnienia odpowiednich przesłanek: wykazanie celu publicznego, niezbędność jego realizacji, zgodność z planem miejscowym lub z decyzją o ustaleniu lokalizacji inwestycji celu publicznego. Pojawia się tu niejednokrotnie problem z zakwalifikowaniem danego działania jako cel publiczny. Wśród niewielkiej liczby orzeczeń sądów w materii celów publicznych na gruncie prawa ochrony środowiska, warte zauważenia jest rozstrzygnięcie WSA w Łodzi w sprawie regulacji rzeki poprzez zastosowanie umocnień technicznych ciężkich wykonanych przez inwestora - Spółkę z o.o. ${ }^{23}$ Sąd ustalił, że regulacja i utrzymywanie wód oraz urządzeń melioracji wodnych jest celem publicznym, o ile są one własnością Skarbu Państwa. W dalszym uzasadnieniu Sąd stwierdził, iż „budowa urządzeń tego typu, niebędących własnością Skarbu Państwa lub jednostek samorządu terytorialnego, chociażby służąca pożytecznym celom gospodarczym, nie będzie nosiła znamion «publiczności», co wywoła ten skutek, iż niedopuszczalne będzie wywłaszczenie gruntów pod budowę urządzeń melioracyjnych należących do innych podmiotów". Kryterium publiczności celu stanowił w tym wypadku podmiot, któremu przysługuje prawo własności, jak również lokalne znaczenie inwestycji, w szczególności ochrona przeciwpowodziowa terenów gminnych. Odmowa wszczęcia postępowania wywłaszczenia uzasadniona jest w przypadku braku powyższych przesłanek (cel publiczny, niezbędność realizacji, zgodność z planem lub decyzją). Gdyby przyjąć założenie o swobodnym uznaniu organu, oznaczałoby to uprawnienie starosty do decydowania m.in. o realizacji zadań publicznych przez gminę, a to ze względu na samodzielność jednostek samorządu terytorialnego nie może zostać zaakceptowane. ${ }^{24}$ Jednak regulacja dotycząca odmowy w formie decyzji wydaje się pozytywna przez wzgląd na to, że umożliwia j.s.t. lub podmiotowi realizującemu cel publiczny podważenie stanowiska starosty poprzez odwołanie i skargę do sądu. 
Wszczęcie postępowania wywłaszczeniowego rodzi obowiązki starosty w zakresie wpisów do ksiąg wieczystych, mówi o tym art. 117 u.g.n. Po pierwsze, starosta zobowiązany jest do złożenia we właściwym sądzie wieczystoksięgowym wniosku o dokonanie wzmianki w księdze wieczystej nieruchomości będącej przedmiotem postępowania wywłaszczeniowego, o wszczęciu takiego postępowania. W sytuacji, gdy nieruchomość nie ma założonej księgi wieczystej, obowiązek ten polega na złożeniu zawiadomienia o wszczęciu postępowania do istniejącego zbioru dokumentów. Po drugie, starosta jest ustawowo zobowiązany do wystąpienia o wykreślenie wpisu o wszczęciu postępowania wywłaszczeniowego z księgi wieczystej, niezwłocznie po tym, gdy okaże się, że postępowanie to nie doszło do skutku. W przypadku braku księgi wieczystej starosta składa zawiadomienie do zbioru dokumentów. Ten drugi obowiązek wynika z tego, że nie każde wszczęte postępowanie wywłaszczeniowe w rezultacie skończy się wywłaszczeniem.

Kolejnym działaniem starosty w trakcie wywłaszczania nieruchomości jest przeprowadzenie rozprawy. Odbywa się ona zgodnie z ogólnymi przepisami k.p.a., zatem tutaj wspomnę jedynie o odrębnościach, jakie w tym zakresie wprowadza u.g.n. Zgodnie z art. 118 ustawy, rozprawa administracyjna w postępowaniu wywłaszczeniowym jest obligatoryjna, z wyjątkiem gdy jego przedmiotem są nieruchomości o nieuregulowanym stanie prawnym. W takiej sytuacji po upływie 2-miesięcznego terminu na zgłoszenie się uprawnionych do nieruchomości osób bez zgłoszenia i wykazania tych praw, starosta wydaje decyzję o nabyciu nieruchomości przez Skarb Państwa lub j.s.t. Obligatoryjność rozprawy wydaje się zrozumiała i uzasadniona z racji doniosłości skutków wywłaszczenia. Służy ona wyjaśnieniu wszelkich okoliczności sprawy, pozwala na wypowiedzenie się stron, organizacji społecznych, przedstawieniu dowodów, co ułatwia organowi wyważenie interesów i podjęcie właściwej decyzji. Jak twierdzi się w nauce prawa, negatywną stroną obligatoryjnej rozprawy jest to, że w pewnych sytuacjach niewymagających uzgadniania interesów ani szczegółowych wyjaśnień z udziałem świadków czy biegłych, może to przedłużać i komplikować postępowanie. ${ }^{25}$ Przeważa jednak argument zastosowania szerokiej ochrony praw strony poprzez dopuszczenie jej do aktywnego udziału w postępowaniu, którego efektem jest władcza ingerencja publicznoprawna w prawo własności jednostki.

Przepis art. 129 ust. 1 wprost upoważnia starostę do ustalenia wysokości odszkodowania za wywłaszczoną nieruchomość. Co do zasady odszkodowanie przyznawane jest w decyzji o wywłaszczeniu, ale ustawa wskazuje kilka wyjątkowych sytuacji, gdy starosta wydaje w tym przedmiocie decyzję odrębną. Wyceny nieruchomości dokonuje rzeczoznawca, po czym zawiera ją w opinii przedkładanej staroście. NSA w wyroku z dnia 8 listopada 2001 r. $^{26}$ wypowiedział się w przedmiocie 
tejże opinii, iż nie ma ona charakteru wiążącego i podlega ocenie właściwego organu administracyjnego. Pojawiają się w tym momencie pewne wątpliwości, które w wyniku braku precyzyjnych regulacji ustawowych próbują rozwiać przedstawiciele nauki prawa. Jeśli bowiem starosta nie ma obowiązku kierowania się opinią rzeczoznawcy, taka dowolność może tworzyć organowi pole do nadużyć. Z drugiej strony całkowite związanie starosty opinią mogłoby powodować takie nadużycia po stronie rzeczoznawcy. Rozsądne rozwiązanie proponuje W. Piątek, którego zdaniem ustalając wysokość odszkodowania należy kierować się opinią rzeczoznawcy określającego wartość nieruchomości, ale w przypadku pojawienia się wątpliwości co do np. sposobu czy wysokości wyceny, istnieje możliwość powołania innego rzeczoznawcy. ${ }^{27} \mathrm{~W}$ takiej sytuacji organ, który dysponuje więcej niż jedną opinią, nie jest związany konkretną opinią. Jest też w tej sprawie stanowisko NSA, który w wyroku z dnia 5 marca 2009 r. $^{28}$ stwierdził, że fakt, iż rzeczoznawca majątkowy z zakresu wyceny nieruchomości jest ekspertem i posiada specjalistyczną wiedzę, nie oznacza, że organy administracji są zwolnione z samodzielnej oceny wartości dowodowej operatu szacunkowego. Rzeczoznawca pełni funkcję biegłego, w związku z czym na mocy przepisów k.p.a. jego opinia podlega swobodnej ocenie jako element materiału dowodowego. To przecież organ podejmuje decyzję o wysokości odszkodowania, zatem to jego obowiązkiem jest podjęcie działań mających na celu prawidłowe ustalenie wartości nieruchomości.

Kolejną kwestią, którą chciałabym poruszyć są cztery uprawnienia starosty przyznane mu na mocy artykułów 122 u.g.n. 124, 125 i 126 u.g.n. Pierwszym jest uprawnienie starosty do wydania decyzji zezwalającej podmiotowi realizującemu cel publiczny na niezwłoczne zajęcie nieruchomości po wydaniu decyzji o wywłaszczeniu. Przesłankami podjęcia takiej decyzji są: wystąpienie przypadków określonych w przepisach k.p.a., przypadków uzasadnionych ważnym interesem gospodarczym oraz zagrożenie, że zwłoka w zajęciu nieruchomości uniemożliwiłaby realizację celu publicznego. Drugie uprawnienie polega na możliwości ograniczenia korzystania z nieruchomości w drodze decyzji zezwalającej na zakładanie i przeprowadzenie na nieruchomości ciągów, przewodów i innych urządzeń. Jest to działanie ograniczone wymogiem zgodności z planem miejscowym lub decyzją o ustaleniu lokalizacji inwestycji celu publicznego. Następnym jest upoważnienie starosty do wydawania decyzji ograniczającej korzystanie z nieruchomości niezbędnej do poszukiwania, rozpoznawania i wydobywania kopalin. Jest to ograniczenie czasowe i może nastąpić jedynie na rzecz przedsiębiorcy posiadającego koncesję na taką działalność. Ostatnim uprawnieniem z tej grupy jest wydawanie decyzji zezwalających na czasowe zajęcie nieruchomości w przypadku siły wyższej lub nagłej potrzeby zapobieżenia powstaniu znacznej szkody. Zauważyć należy, że wszyst- 
kie powyższe działania starosty obwarowane są ustawowymi przesłankami, które muszą zostać spełnione, aby dana decyzja mogła zostać wydana. Nie ma tu miejsca na uznanie organu.

Warto w tym momencie zwrócić uwagę na wynikającą z art. 131 Prawa ochrony środowiska kompetencję starosty do ustalenia wysokości odszkodowania za ograniczenie sposobu korzystania $\mathrm{z}$ nieruchomości w związku z ochroną zasobów środowiska przez poddanie ochronie obszarów lub obiektów na podstawie przepisów o ochronie przyrody. Mamy tu do czynienia z sytuacją, w której korzystanie z nieruchomości zostaje uniemożliwione lub na tyle ograniczone, że skutkuje to prawem poszkodowanego do żądania odszkodowania albo wykupu nieruchomości, co nazywane jest wywłaszczeniem przez ograniczenie i ujęte zostało również w art. 124 u.g.n. Zgodnie ze stanowiskiem zawartym w Komentarzu do ustawy p.o.ś., ${ }^{29}$ art. 132 p.o.ś. nastręcza wielu problemów w interpretacji, gdyż nie wskazuje, które konkretnie zasady i tryb określone w u.g.n. mają być stosowane w tym przypadku. W dalszych przepisach p.o.ś. wskazuje się na tryb ustalenia przez starostę odszkodowania odpowiadający przepisom u.g.n. (wycena nieruchomości oraz uzyskanie opinii rzeczoznawcy), jednak w kwestii podmiotów obowiązanych do wypłaty odszkodowania zauważa się pewien dysonans $w$ relacji z przepisami u.g.n.

\section{Podsumowanie}

Wydaje się, że zestawienie ochrony środowiska z interesem jednostkowym ukierunkowanym na ochronę prawa własności miało, ma i zawsze będzie miało cechy konfliktu. Zrównoważony rozwój wskazywany jest jako zasada służąca rozwiązywaniu sporów na tym polu poprzez bilansowanie korzyści i strat w odniesieniu do trzech sfer: gospodarki, społeczeństwa oraz środowiska, jako tzw. „złoty środek”. Próba łagodzenia tych konfliktów jest trudnym zadaniem starosty jako organu prowadzącego postępowanie wywłaszczeniowe. Jednocześnie, co należy podkreślić, starosta jest organem ochrony środowiska wg art. 376 ustawy Prawo ochrony środowiska, zatem jego działania w zakresie wywłaszczenia nie powinny być prowadzone w oderwaniu od działań związanych z ochroną środowiska. Katalog celów publicznych zawarty w art. 6 u.g.n. praktycznie w całości mieści się w zakresie treściowym pojęcia zrównoważony rozwój zawartego w art. 3 pkt 50 ustawy Prawo ochrony środowiska. Samo wywłaszczenie ma służyć rozwojowi społeczno-gospodarczemu i zaspokajaniu potrzeb zbiorowości, w tym ochronie dobra publicznego, jakim jest środowisko.

Wywłaszczenie było stosowane jako podstawowy instrument przemian w czasach przebudowy systemu gospodarczego, kiedy w konsekwencji szerokiego ujmo- 
wania celów publicznych oraz przyznawania nieekwiwalentnego odszkodowania prowadziło do niezliczonej liczby nadużyć. ${ }^{30}$ Kolejne nowelizacje, chociaż część z nich oceniana jest krytycznie, doprowadziły do coraz rzadszego ingerowania w prawo własności w sposób najbardziej dotkliwy. Nie oznacza to jednak, że wywłaszczenie dzisiaj stanowi mniej znaczącą instytucję. Jej rangę ukazuje chociażby program budowy płatnych autostrad i uchwalona w celu jego realizacji ustawa $\mathrm{z}$ dnia 27 października 1994 r. o autostradach płatnych oraz o Krajowym Funduszu Drogowym. ${ }^{31}$ Idea wybudowania ok. $2600 \mathrm{~km}$ autostrad miała w założeniach dotyczyć ok. 100000 właścicieli nieruchomości. ${ }^{32} \mathrm{~W}$ rzeczywistości pozostano jednak tylko przy założeniach.

Starosta w postępowaniu wywłaszczeniowym wykonuje zadania z zakresu administracji rządowej. Nie działa tu zatem jako przewodniczący zarządu powiatu, gdyż ta funkcja należy do sfery administracji samorządowej. W przypadku, gdy stroną wywłaszczenia jest powiat, reprezentujący go starosta ulega wyłączeniu z postępowania i prowadzone jest ono przez organ wyższego stopnia. Rolą starosty jest stworzenie podmiotowi wywłaszczanemu odpowiednich gwarancji procesowych, bo bez nich ingerencja publicznoprawna w prawo własności indywidualnego podmiotu nie jest dopuszczalna w demokratycznym państwie prawnym. W mojej opinii można również rolę tę interpretować jako rolę strażnika przestrzegania zasady zrównoważonego rozwoju. Organ ten musi zapewniać takie prowadzenie postępowania, by było ono zgodne z ukształtowaną procedurą, by podmiot wywłaszczany był świadomy niezbędności ingerencji w jego prawa dla realizacji celu publicznego i by nadrzędność owego celu została mu w pełni zrekompensowana za pomocą stosownego odszkodowania. ${ }^{33}$

Warto jeszcze zwrócić uwagę na przepisy Konstytucji RP z 1997 r. ${ }^{34}$ dotyczące zrównoważonego rozwoju oraz ich relację z przepisami o wywłaszczeniu. Zasada zrównoważonego rozwoju, która ujęta została w art. 5 Ustawy Zasadniczej, tworzy wytyczne do realizacji zadań dla całego aparatu państwa. Zgodnie z nim strzeżenie niepodległości i nienaruszalności terytorium, zapewnianie wolności i praw człowieka i obywatela oraz bezpieczeństwa obywateli, strzeżenie dziedzictwa narodowego i ochrona środowiska, to zadania państwa, które mają być realizowane zgodnie z zasadą zrównoważonego rozwoju. Trzeba jednak zauważyć, że w nauce prawa nie osiągnięto dotychczas konsensusu w kwestii, czy zasada zrównoważonego rozwoju odnosi się rzeczywiście do wszystkich wymienionych w powoływanym artykule zadań państwa, czy tylko do ochrony środowiska. W mojej opinii bardziej odpowiedni jest szerszy kontekst, za dyrektywę obowiązującą organy wła-

T. Woś, Wywłaszczenie..., op. cit., s. 13.

T.j. Dz.U. z 2012 r., poz. 931.

T. Woś, Wywłaszczenie..., op. cit., s. 14.

Ibidem, s. 74.

Konstytucja Rzeczypospolitej Polskiej z dnia 2 kwietnia 1997 r., Dz.U. Nr 78, poz. 483 ze sprost. i zm. 
dzy publicznej należy uznać integrowanie działań, wyważanie interesów i osiąganie kompromisów w dążeniu do zaspokajania potrzeb obecnych i przyszłych pokoleń. Wypływa z tego wniosek, że taki obowiązek obciąża również starostę w ramach procedury wywłaszczeniowej. 


\section{DISTRICT GOVERNOR'S ACTIVITIES IN THE PROCEDURE OF EXPROPRIATION OF REAL ESTATE WITH THE AIMS RELATED TO ENVIRONMENTAL PROTECTION}

The object of this article is analysis of a district governor's role in the scope of expropriation of real estate, as the body competent within this procedure. Widely understood expropriation may be favourable to the principle of sustainable development, but, on the other hand, may frequently cause conflict of interests. The district governor's task is therefore to mitigate such conflict by means of balancing interests and achieving compromise in heading to satisfy the social-economic needs of present and future generations. The Author indicates the review of competences of a district governor as the body within government administration, beginning with opening negotiations, through duties related to issues of damages and land and mortgage registers, till the moment when the decision on expropriation is final and valid. All of them are to establish guaranties to the subject of proceedings, that expropriation is the ultima ratio measure, and is being held in accordance with the legal procedure and the principle of democratic state of law, including the principle of sustainable development.

Keywords: expropriation, district governor, sustainable development, conflict of interests 